\title{
INTERNATIONAL OPHTHALMOLOGICAL CONGRESS, 1929
}

\section{Subscribers to International Ophthalmological Council Fund}

\author{
THIRD LIST
}

Societies, Institutions, etc.

\author{
Archivos de Ottalmologia Hispano- \\ Americanos. \\ British Medical Association. \\ Czecho - Slovalian Ophthalmological \\ Society. \\ Japanese Ophthalmological Society. \\ Oxford Ophthalmological Congress.
}

\author{
Royal Westminster Ophthalmic \\ Hosp:tal. \\ Section on Ophthalmology, Collegie of \\ Physicians of Philadelphia. \\ Ophthalmological Society of Egypt. • \\ Ophthalmological Society of Valparaiso. \\ Ophthalmological Society of IVarsaw.
}

Ask, Fritz.

('haillous, J.

Cirincione, Giuseppe.

Cirincione, Speciale.

Cozzoli, Giulio.

I)alén, Albin.

Fileti, Antonio.

Finnoff, Wm. C.

Gomès, Percira.
Roselli, Remeo.

Sartain, Paul J.

Snell, H. C.

Terrien, F.

Velez, Danicl II

Wardale, J. D.

Zappala, Antonino.
Oguchi, Chuta.

Picciche, Speciale.

Radcliffe, McCluney.

\section{ABSTRACTS}

\section{I.-REPORT OF COMMITTEE ON OPTICIANS' (REGISTRATION) BILL}

\section{* Report of the Committee appointed by the Minister of Health and the Secretary of State for Scotland on the Optical Practitioners' (Registration) Bill, I927.}

The Committee appointed last year to consider the Optical Practitioners' (Registration) Bill (Brit. Jl. of Ophthal., Vol. XI, p. 235, 192 ) has issued its report consisting of a majority report, signed by nine members including the chairman, and two minority reports, signed by three members and one member respectively,

\footnotetext{
${ }^{*}$ Pp. 27. H.M. Stationery Office, London, 1927. Price 6d.
} 